\title{
PERSPEKTIF EKONOMI ISLAM PADA PENGOLAHAN LIMBAH PLASTIK (STUDI PADA SISTEM PRODUKSI DI UD. WAHYU PLASTIK)
}

\author{
Muhamad Turmudi \\ Fakultas Ekonomi dan Bisnis Islam Institut Agama Islam Negeri Kendari \\ mturmudi76@gmail.com
}

\begin{abstract}
This research aims to investigate the business model of plastics recycling at UD. Wahyu Plastik based on Islamic economics perspective. This research uses descriptive qualitative method. The data is collected by observation, interview and document study. The results indicate that production factors: the land as a place of business is a privately owned by business owners, labor is positioned in place accordance with the needs of production, so there is no wastage of employees' wages, private capital and proceeds derived from bank loans, management functions apply to all stages of production, the raw materials, used plasctics, purchased from suppliers with the price of both sides agree. Plastics recycling of UD. Wahyu Plastik is limited to grinding the plastics into small pieces not yet ready for pellets/plastics seeds production or ready-made products. The recycling prosess is conducted through some stages: separating raw materials by type and color; cleaning and washing; milling of raw materials; drying of the mill; packing the dried mill into the sack. Palstics recycling business opportunity is formed due to the mutual effort of the collectors, plastics waste processors and manufacturers of finished products.
\end{abstract}

Keywords: waste plastic, recycling, production factors, production processes, business opportunities

\begin{abstract}
Abstrak
Penelitian ini dilakukan untuk mengetahui model bisnis pengolahan limbah plastik UD. Wahyu Plastik berdasarkan perspektif ekonomi Islam. Penelitian ini menggunakan metode kualitatif deskriftif dengan cara observasi, wawancara dan studi dokumen. Hasil penelitian menunjukkan bahwa tanah sebagai tempat usaha merupakan milik pribadi pemilik usaha. Tenaga kerja diposisikan pada tempat sesuai dengan kebutuhan produksi sehingga tidak terjadi pemborosan upah karyawan. Modal yang bersumber dari pribadi dan hasil pinjaman di bank. Fungsi manajemen diberlakukan pada semua tahapan produksi, bahan baku berupa plastik bekas yang dibeli dari para pemasok dengan harga kesepakatan kedua belah pihak.
\end{abstract}


Pengolahan limbah plastik yang dilakukan UD. Wahyu Plastik sebatas menggiling plastik bekas menjadi potongan kecil belum pada tahap produksi pellet/biji plastik ataupun produk siap pakai. Produksi yang dilakukan UD. Wahyu Plastik melalui beberapa proses yaitu pemisahan bahan baku berdasarkan jenis dan warna, pembersihan dan pencucian dari kotoran seperti tanah, kertas atau besi, penggilingan yaitu menggiling bahan baku sehingga menjadi potongan kecil, pengeringan yaitu mengeringkan hasil gilingan, pengepakan yaitu memasukkan hasil gilingan yang sudah dikeringkan ke dalam karung dan siap untuk dipasarkan. Peluang usaha pengolahan limabah plastik terbentuk karena adanya usaha yang saling membutuhkan dari para pengepul/pemulung, pengolah limbah plastik serta pabrik pembuat produk jadi.

Kata Kunci: limbah plastik, daur ulang, faktor produksi, proses produksi, peluang usaha

\section{A. Pendahuluan}

Salah satu tujuan bisnis yaitu dapat memenuhi kebutuhan dan keinginan manusia, yakni dengan melakukan produksi. Untuk dapat mempertahankan hidupnya, manusia membutuhkan makan, minum, pakaian dan perlindungan, ${ }^{1}$ sehingga produk tidak dapat dilepaskan dengan kebutuhan. ${ }^{2}$ Namun demikian, proses produksi dapat menghasilkan limbah buangan yang salah satunya adalah plastik. Plastik merupakan material yang banyak digunakan sehingga banyak menghasilkan limbah, padahal plastik membutuhkan waktu 50 sampai 100 tahun $^{3}$ baru bisa terurai secara alamiah bahkan banyak jenis plastik yang baru terurai setelah 450 tahun. ${ }^{4}$ Membakar limbah plastik dapat memperpendek umur sampah plastik serta menguranginya, namun demikian kandungan limbah sampah plastik yang terlepas ke udara dapat membahayakan kesehatan mahluk hidup termasuk manusia. Penanganan terhadap limbah plastik berarti melakukan suatu produksi dengan menciptakan nilai barang atau menambah nilai bagi limbah plastik yang sudah diolah.

Plastik merupakan material yang banyak digunakan dalam kehidupan manusia, bahkan hampir semua produk memiliki kemasan yang berbahan

1 Chalil, Zaki Fuad, Pemerataan Distribusi Kekeyaan dalam Ekonomi Islam, (Jakarta: Erlangga, 2009), h. 86.

${ }^{2}$ Gitosudarmo, H. Indriyo, Manajemen Operasi, Edisi Kedua, (Yogyakarta: BPFE Yogyakarta, 2002), h. 67.

3“Hindari Budaya Nyampah". http://www.p-wec.org/id/go-green/hindari-budayanyampah. Diakses tanggal 5 Desember 2015.

${ }^{4}$ Bongardt, Benjamin, Masalah Sampah Plastik. http://www.dw.com/id/masalahsampah-plastik/g-17164855. Diakses tanggal 5 Desember 2015. 
plastik baik sebagai bungkus kemasan ataupun hanya sekedar label merk produksi, hal itu disebabkan karena bahan plastik memiliki banyak kelebihan transparan, tahan air, serta harganya relatif terjangkau oleh semua kalangan masyarakat. Dengan beragam keunggulan tersebut penggunaan plastikpun akan terus bertambah yang akibatnya jumlah produk plastik yang akan menjadi sampahpun terus bertambah. Padahal sampah plastik merupakan sampah yang dapat didaur ulang menjadi barang-barang yang berguna bahkan menjadi barang yang bernilai bila dikerjakan oleh orangorang yang kreatif.

UD. Wahyu plastik merupakan salah satu unit usaha yang bergerak di bidang pengolahan limbah plastik di Kota Kendari, hal tersebut terlihat dari adanya aktifitas pengolahan mulai dari menyortir bahan baku, membersihkan serta menggilingnya menjadi produk yang bisa laku dipasar, sehingga membantu untuk mengurai sampah plastik menjadi bahan baku produk siap jadi.

Tulisan mengenai pengolahan limbah plastik sudah banyak dilakukan, diantaranya penelitian yang dilakukan Dyah Purwaningsih (Staff Jurdik Kimia UNY) berjudul Pemanfaatan Daur Ulang Limbah Plastik Dan Logam Untuk Sumber Pembuatan Peraga Pendidikan Inovatif yang menyatakan bahwa pemanfaatan limbah plastik dan logam dapat dilakukan dengan pemakaian kembali (reuse) maupun daur ulang (recycle), salah satu pemanfaatannya adalah sebagai sumber peraga pendidikan yang inovatif. ${ }^{5}$ Penelitian lain ditulis oleh Irma Hardi Pratiwi, Sritomo Wignjosoebroto, dan Dyah Santhi Dewi berjudul Sistem Pengelolaan Sampah Plastik Terintegrasi Dengan Pendekatan Ergonomi Total Guna Meningkatkan Peran Serta Masyarakat (Studi Kasus: Surabaya), hasil dari penelitian tersebut menggambarkan pengelolaan sampah plastik dapat disusun melalui sistem terintegrasi dengan pendekatan ergonomi total yaitu integrasi antara ergonomi mikro dan makro. Integrasi keduanya membawa kerangka kerja dalam mengoptimalkan kesesuaian antara manusia, teknologi dan organisasional. ${ }^{6}$

5 Purwaningsih, Dyah, Pemanfaatan Daur Ulang Limbah Plastik Dan Logam Untuk Sumber Pembuatan Peraga Pendidikan Inovatif, http://staff.uny.ac.id/. Diakses tanggal 8 Desember 2015.

${ }^{6}$ Pratiwi, Irma Hardi, Sritomo Wignjosoebroto, dan Dyah Santhi Dewi, Sistem Pengelolaan Sampah Plastik Terintegrasi Dengan Pendekatan Ergonomi Total Guna Meningkatkan Peran Serta Masyarakat (Studi Kasus : Surabaya), http://dosen.narotama.ac.id/. Diakses tanggal 10 Maret 2016. 
Penelitian pengolahan limbah plastik yang dilakukan di UD. Wahyu Plastik ingin mengetahui bagaimana tinjauan ekonomi Islam terhadap faktor-faktor produksi serta proses produksi dalam kaitannya dengan pengolahan limbah di UD. Wahyu Plastik.

\section{B. INDUSTRI LIMBAH PLASTIK}

Limbah plastik merupakan salah satu jenis sampah rumah tangga yang punya peran besar dalam perusakan lingkungan. Plastik yang dibuang lama kelamaan akan menumpuk dan terkubur dalam tanah sehingga dapat mengganggu struktur dan kesuburan tanah bahkan dapat mencemari aliran sungai. ${ }^{7}$ Kehadiran industri pengolahan plastik menjadi produk siap pakai sangat membantu mengatasi masalah limbah plastik. Industry berarti upaya manusia untuk menciptakan guna atau menambah guna suatu barang, dengan mempergunakan akal, ilmu dan keterampilannya dapat memproduksi sesuatu yang bermanfaat dan lebih berguna. ${ }^{8}$

Berdasarkan bahannya, sampah rumah tangga dan limbah industri terbagi kepada tiga jenis, yaitu:

a. Sampah organik yaitu sampah yang terdiri dari bahan-bahan yang mudah terurai seperti limbah makanan serta daun-daun kering.

b. Sampah anorganik yaitu sampah berasal dari bahan-bahan yang sulit terurai seperti plastik, kaleng dan styrofom.

c. Sampah berbahaya/beracun yaitu sampah berasal dari bahan-bahan berbahaya/beracun seperti limbah yang berasal dari rumah sakit atau limbah yang berasal dari pabrik. ${ }^{9}$

Untuk mengurangi limbah plastik dapat dilakukan dengan cara (1) reduce yaitu mengurangi barang/material yang kita gunakan (2) reuse yaitu menggunakan kembali barang yang sudah dipakai (3) recycle yaitu mendaurulang barang-barang yang sudah tidak dapat digunakan (4) replace yaitu mengganti barang yang hanya bisa digunakan satu kali dengan barangbarang yang lebih tahan lama ${ }^{10}$ dan dapat digunakan berkali-kali.

Plastik yang bisa didaur ulang dikelompokkan berdasarkan jenisnya, yaitu (1) polyethylene (PET) merupakan plastik yang tahan lama, kuat, ringan dan mudah dibentuk ketika panas (2) high density polyethylene

\footnotetext{
${ }^{7}$ Uno, Mien R dan Siti Gretiani, Buku Pintar Etiket Hijau, (Jakarta: Gramedia, 2011), h. 34

${ }^{8}$ Efendi, Mochtar, Ekonomi Islam Suatu Pendekatan Berdasarkan Ajaran AlQur'an dan Hadits, (Palembang: YPII Al-Muktar, 1996), h. 67.

${ }^{9}$ Daniel, Valerina, Easy Green Living, (Bandung: Hikmah, 2009), h. 35-36

${ }^{10}$ Zulkifli, Arif, Dasar-Dasar Ilmu Lingkungan, (Jakarta: Salemba Teknika, 2014), h. 106
} 
(HDPE) merupakan plastik yang liat, kuat dan kaku, berasal dari minyak bumi yang sering dibentuk dengan cara meniupnya (3) polyvinyl chloride (PVC) merupakan plastik yang liat dank eras serta tidak terpengaruh zat kimia lainnya (4) low density polyethylene (LDPE) merupakan plastik yang keras, kuat, tidak bereaksi terhadap zat kimia lainnya, namun mudah dibentuk ketika panas (5) polypropylene (PP) merupakan plastik yeng lentur, keras dan resisten terhadap lemak serta mudah dibentuk ketika panas (6) polystyrene (PS) merupakan plastik yang sangat kaku dan tidak mudah didaur ulang (7) other merupakan plastik yang terbuat dari campuran dua atau lebih jenis plastik. ${ }^{11}$

\section{PRODUKSI DALAM SISTEM EKONOMI ISLAM}

Ekonomi Islam merupakan suatu pemahaman yang berupaya merealisasikan kebahagiaan manusia melalui alokasi dan distribusi sumberdaya dengan terus berada pada ajaran Islam tanpa mengekang kebebasan individu untuk menciptakan keseimbangan ekonomi dan ekologi yang berkesinambungan. ${ }^{12}$ Sistem ekonomi Islam memandang masalah ekonomi tidak pada sudut pandang kapitalis yang memberikan kebebasan, hak pemilikan kepada individu serta menggalakkan usaha secara perorangan, tidak pula dari sudut pandang sosialis dengan menghapus semua hak individu dan menjadikan masyarakat seperti budak ekonomi yang dikendalikan negara. Islam membolehkan memperhatikan kepentingan pribadi dengan tidak membiarkan merusak masyarakat. ${ }^{13}$ untuk itu, pelaksanaan sistem ekonomi Islam dapat dipraktekkan sehari-hari dalam mengorganisasi faktor produksi, distribusi ataupun memanfaatkan barang dan jasa yang dihasilkan dengan tidak menyalahi al-Qur'an dan al-Sunnah sebagai pedoman aturan perundangan dalam sistem ekonomi Islam. ${ }^{14}$

Prinsip yang terdapat dalam sistem ekonomi Islam dapat dirangkum dalam empat prinsip, yaitu:

a. Tauhid; prinsip tauhid merupakan prinsip pertama dan utama dalam sistem ekonomi Islam, karena dari prinsip tauhidlah lahir prinsip-

\footnotetext{
${ }^{11} \mathrm{http} / / /$ www.gogreencharleston.org. Diakses tanggal 10 Maret 2016.

${ }^{12}$ Fauzia, Ika Yunia dan Abdul Kadir Riyadi, Prinsip Dasar Ekonomi Islam: Perspektif Maqashid al-Syari'ah, (Jakarta: Prenadamedia Group, 2014), h. 7.

${ }^{13}$ Rahman, Afzalur, Economic Doctrines of Islam, Terj. Soeroyo Nastangin, "Doktrin Ekonomi Islam", Jilid 2, (Yogyakarta: Dana Bhakti Wakaf, 1995), h. 10

${ }^{14}$ Lubis, Suhrawardi K, Hukum Ekonomi Islam, Cet. 1, (Jakarta: Sinar Grafika, 2000), hal. 14
} 
prinsip yang menyangkut segala aspek kehidupan dunia dan akhirat ${ }^{15}$ yang segala sesuatu bersumber dan kesudahannya kepada Allah swt.

b. Keadilan dan keseimbangan; prinsip keadilan merupakan landasan untuk menghasilkan seluruh kebijakan dalam kegiatan ekonomi sehingga berdampak positif bagi pertumbuhan, pemerataan pendapatan serta kesejahteraan bagi semua masyarakat. Prinsip keseimbangan berarti mencerminkan kesetaraan pendapatan dengan pengeluaran, pertumbuhan dengan pendistribusian serta pendapatan kaum yang mampu dan kaum yang kurang mampu. ${ }^{16}$

c. Kehendak bebas; manusia memiliki kebebasan untuk memilih apa yang akan diperbuatnya, namun manusia yang baik adalah manusia yang mampu menggunakan kebebasan dalam menerapkan tauhid dan keseimbangan. ${ }^{17}$

d. Tanggung Jawab; kebebasan setiap orang untuk mengambil pekerjaan atau memanfaatkan kekayaan tentunya harus tetap dipertanggungjawabkan.

Kegiatan produksi dalam ekonomi Islam terkait dengan manusia dan eksistensinya dalam aktivitas ekonomi yang dapat menciptakan kekayaan dengan memanfaatkan sumber alam bukan berarti hanya menciptakan sesuatu yang benar-benar baru, melainkan juga membuat barang-barang menjadi berguna. Menciptakan nilai atau menambah nilai terhadap suatu produk, barang dan jasa yang diproduksi harus yang dibolehkan dan menguntungkan (yakni halal dan baik) menurut Islam. ${ }^{18}$

Tujuan produksi dalam Islam pada dasarnya adalah untuk menciptakan maṣlaḥah yang optimum bagi manusia secara keseluruhan sehingga tercapai falāh (kebahagiaan di dunia dan di akhirat). Dalam ekonomi Islam, prinsip produksi diatur berdasarkan maqashid al-syari'ah antara lain yaitu:

a. Semua aspek kegiatan produksi harus dilandasi nilai-nilai Islam yakni tidak diperbolehkan memproduksi sesuatu yang yang bertentangan dengan penjagaan terhadap agama, jiwa, akal, keturunan serta harta.

b. Prioritas produksi harus sesuai dengan prioritas kebutuhan yaitu:

\footnotetext{
${ }^{15}$ Shihab, M. Quraish, Menabur Pesan Illahi Al-Qur'an dan Dinamika Kehidupan Masyarakat, (Jakarta: Lentera Hati, 2006), h. 198

${ }^{16}$ Nata, Abuddin, Studi Islam Komprehenshf, (Jakarta: Kencana Prenada Media Group, 2011), h. 415

${ }^{17}$ M. Quraish Shihab, off cit, h. 403

${ }^{18}$ Haneef, Mohamed Aslam, Pemikiran Ekonomi Islam Kontemporer, terj. Suherman Rosyidi, (Jakarta: Rajawali, 2010), h. 29
} 
1) Kebutuhan dharuriyyat (kebutuhan primer); kebutuhan yang harus ada dan terpenuhi yang merupakan perlindungan terhadap keselamatan agama, nyawa, akal, keturunan, harta kekayaan serta harga diri dan kehormatan seseorang.

2) Kebutuhan hajiyyat (kebutuhan sekunder); kebutuhan yang diperlukan manusia, namun tidak sampai mengancam eksistensi kehidupan manusia menjadi rusak, melainkan hanya sekedar menimbulkan kesulitan dan kesukaran.

3) Kebutuhan tahsiniyyat (kebutuhan tersier); kebutuhan yang mendukung kemudahan dan kenyamanan hidup manusia. ${ }^{19}$

c. Dalam berproduksi harus memperhatikan beberapa aspek yaitu keadilan, sosial, zakat, sedekah dan infak.

d. Dalam mengelola sumberdaya alam haruslah optimal, tidak boros/berlebihan serta tidak boleh merusak lingkungan.

e. Mendistribusikan keuntungan secara adil antara pemilik dan pengelola ataupun manjemen dan buruh. ${ }^{20}$

Istilah produksi dalam ekonomi merupakan siklus kegiatan yang menghasilkan barang atau jasa dengan memanfaatkan faktor-faktor produksi dalam jangka waktu tertentu. ${ }^{21}$ Faktor produksi tersebut yaitu:

a. Alam/tanah yakni bumi dan segala isinya yang dikategorikan sebagai sumber alam yang dapat dimanfaatkan untuk kesejahteraan dan kemakmuran umat manusia. ${ }^{22}$

b. Tenaga kerja, merupakan faktor pendaya guna faktor alam dengan hak untuk mendapatkan upah/gaji dari hasil pekerjaannya, mendapatkan jaminan kerja dari pihak pemberi kerja, mendapatkan pelayanan kesehatan dan tujuan sosial lainnya serta mendapatkan pendidikan agar kualitas bekerja dari para pekerja semakin meningkat. ${ }^{23}$

c. Modal (capital); merupakan sejumlah daya beli atau yang dapat menciptakan daya yang dipergunakan untuk suatu proses produksi, tanpa modal maka tidak dapat berproduksi. ${ }^{24}$

${ }^{19}$ Koto, H. Alaiddin, Ilmu Fiqih dan Ushul Fiqih, (Jakarta: Grafindo Pratama, 2004), h. 123.

${ }^{20}$ Fauzia, Ika Yunia dan Abdul Kadir Riyadi, h. 128

${ }^{21}$ Djazuli, A., Yadi Janwari, Lembaga-Lembaga Perekonomian Umat (Sebuah Pengenalan), (Jakarta: PT. Raja Grafindo Persada 2002), h. 27

${ }^{22}$ Ibid.

${ }^{23}$ Ibid, h. 30

${ }^{24}$ Effendi, Mochtar,... op. cit., h. 49 
d. Manajemen; merupakan proses mengatur sumberdaya manusia ataupun sumberdaya lainnya untuk mencapai tujuan tertentu secara efektif dan efisien. ${ }^{25}$

\section{SISTEM GAJI/UPAH TENAGA KERJA}

Gaji merupakan kompensasi atau imbalan dalam bentuk uang sebagai imbalan atas pelaksanaan tanggung jawab suatu pekerjaan. ${ }^{26}$ Sedangkan upah merupakan imbalan yang diterima atas jasa kerja yang diberikan dalam proses produksi sehingga mampu meningkatkan produktivitas pekerja. ${ }^{27}$ Selain gaji pokok pekerja juga dapat memperoleh upah dari hasil komisi penjualan yang merupakan rencana intensif individu yang memberikan penghargaan terhadap karyawan dengan suatu presentase volume penjualan yang dihasilkannya. ${ }^{28}$

Ketentuan penetapan upah dalam Islam harus disebutkan sebelum pekerjaan di mulai, hal tersebut berdasarkan hadits Rasulullah SAW yang diriwayatkan oleh Abdurrazak dari Abi Said al-Khudri ra. sesungguhnya Nabi SAW bersabda:

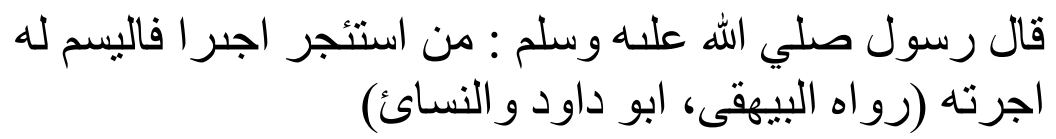

Artinya: Barang siapa mempekerjakan seorang pekerja, maka harus disebutkan upahnya" (H.R. Baihaqi, Abu Dawud dan Nasa'i).

Selain penetapan besaran upah yang disepakati diawal masa kerja, Islam mengajarkan untuk tidak menunda-nunda membayarkan upah tenaga kerja karena mereka mereka memilki hak untuk dibayar atas pekerjaannya sesuai perjanjian.

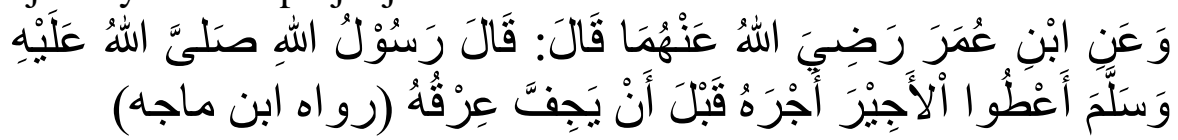

Artinya: Dari Ibnu Umar r.a menceritakan bahwa Rasulullah saw. bersabda: bayarlah upah/gaji itu sebelum kering keringat pekerjanya. ${ }^{29}$

\footnotetext{
${ }^{25}$ Hasibuan, Malayu S.P., Dasar-dasar Perbankan, (Jakarta: Bumi Aksara, 2004), hal. 54

${ }^{26}$ Griffin, Ricki W, et al, Bisnis, Alih Bahasa Edina C. Tarmidzi, Edisi 6, (Jakarta: Prenhallindom, 2003), h. 256

${ }^{27}$ Simanjuntak, Payaman, Manajemen Hubungan Industrial, (Jakarta: Pustaka Sinar Harapan, 2003), h. 129

${ }^{28}$ Griffin, Ricki W, op. cit.., h. 259

${ }^{29}$ Mansyur, Kahar, Bulughul Maram, (Jakarata: PT. Rineka Cipta, 1992), h. 515
} 
Islam memberikan kebebasan dalam menentukan waktu pembayaran upah, yakni berdasarkan kesepakatan antara pekerja dengan yang memberi pekerjaan sehingga keduanya sama-sama mengerti dan tidak ada yang merasa dirugikan. ${ }^{30}$ Namun demikian, dengan adanya penetapan kesepakan besaran upah serta dibayarkan tepat waktu dapat menghilangkan keraguan/kekhawatiran pekerja akan tidak terbayarkannya upah mereka atau dalam pembayarannya mengalami keterlambatan.

Sistem pengupahan dalam Islam juga berpedoman pada nilai keadilan dan kelayakan sehingga tidak terjadi tindakan aniaya terhadap orang lain juga tidak merugikan kepentingannya sendiri, majikan membayar para pekerja dengan bagian yang seharusnya mereka terima sesuai dengan pekerjaannya $^{31}$ serta berdasar pada tingkat kelayakan upah yang ditetapkan pemerintah.

\section{E. SEKILAS UD. WAHYU PLASTIK}

UD. Wahyu Plastik merupakan badan usaha milik perorangan yang bergerak pada pengolahan limbah plastik yang berlokasi di wilayah NangaNanga Kota Kendari yang beroperasi pada tahun 2012. Pada tahun 2014 perusahaan mengalami penurunan omset bahkan hampir mengalami kebangkrutan. Tahun 2015 UD. Wahyu Plastik bangkit kembali dengan beberapa perbaikan dengan menambahkan modal melalui pinjaman pada lembaga perbankan. Setelah mengalami perbaikan-perbaikan usaha, UD. Wahyu Plastik memiliki 9 orang tenaga kerja dengan jumlah pemasok tidak dibatasi yakni siapa saja yang mau menjual plastik bekas akan diterima dengan harga yang sudah ditetapkan berdasarkan jenis plastik.

Setiap orang yang menjadi bagian di UD. Wahyu Plastik memiliki pekerjaan berdasarkan tugas masing-masing, yaitu (1) Pimpinan perusahaan yang bertanggung jawab penuh atas perkembangan usaha perusahaan, memonitoring kerja para karyawan, mencari/menyediakan bahan baku plastik, memberikan upah/gaji para karyawan serta memasarkan hasil produksi (2) bagian mensortir bahan baku yaitu bagian yang memilih/memisahkan dan mengelompokkan limbah plastik berdasarkan jenis dan warna plastik (3) bagian membersihkan bahan baku yang memiliki tugas membersihkan bahan baku dari kotoran seperti tanah atau label merek yang terbuat dari kertas dan bahan lainnya, mencuci bahan baku yang

${ }^{30}$ Hadiyan, Edwin, "Sistem Pengupahan Tenaga Kerja Ditinjau Dari Prinsip Fiqih Muamalah Dan Undang-undang No. 13 tahun 2003 Tentang Ketenagakerjaan”, Jurnal Bisnis dan Manajemen, Vol. 3 No.1, (2-15): 24-33.

${ }^{31}$ Rahman, Afzalur, Loc Cit, h. 363-364 
sudah dibersihkan, menggencet bahan baku jenis botol atau gelas bekas air mineral menjadi tipis serta mengeringkan bahan baku sebelum digiling/rajah (4) bagian yang menggiling limbah plastik yang bertugas memasukkan bahan baku yang sudah dibersihkan dan dikeringkan ke dalam mesin penggilingan sehingga akan menghasilkan potongan-potongan kecil sesuai ukuran mesin potong, mencampur air pada saat bahan baku digiling, mengeringkan hasil gilingan yang sudah dibersihkan seta mengepak/memasukkan hasil gilingan yang sudah kering kedalam karung. ${ }^{32}$

\section{F. FAKTOR PRODUKSI LIMBAH PLASTIK DI UD. WAHYU PLASTIK KENDARI}

Produksi merupakan siklus kegiatan ekonomi guna menghasilkan barang atau jasa dengan memanfaatkan faktor produksi dalam jangka waktu tertentu. ${ }^{33}$ Faktor produksi dapat dibedakan berdasarkan jumlah penggunaannya, yaitu 1) faktor produksi tetap (fixed input) merupakan faktor produksi yang jumlah penggunaannya tidak tergantung pada jumlah produksi sehingga ada ataupun tidak ada kegiatan produksi, faktor produksi tersebut haruslah ada; 2) variable tetap (variable input) merupakan faktor produksi yang jumlah penggunaannya berdasarkan tingkat produksinya, semakin besar tingkat produksi maka semakin banyak variable tetap yang digunakan. Faktor-faktor produksi tersebut adalah tanah, tenaga kerja, modal, manajemen produksi, teknologi serta bahan baku. ${ }^{34}$

Faktor-faktor produksi di UD. Wahyu Plastik selaku produsen yang mengolah limbah plastik dapat dijelaskan sebagai berikut:

a. Faktor Tanah

Pengolahan limbah plastik merupakan salah satu bentuk usaha produksi yang memerlukan tempat luas sebagai penyimpan bahan baku, untuk itu kebutuhan akan tanah yang akan digunakan sebagai lokasi usaha sangatlan penting. Tanah yang digunakan sebagai tempat produksi dan penyimpanan bahan baku merupakan milik pimpinan perusahaan sekaligus pemilik usaha sehingga tidak ada biaya produksi khusus yang digunakan sebagai biaya tetap untuk pembayaran tempat usaha selain pajak tanah. Selain tidak ada biaya tetap untuk pembayaran tempat usaha, keuntungan yang diperoleh dengan memiliki tempat sendiri yaitu tidak perlu mencari tempat untuk menjadikan tempat usaha sehingga tanah yang tadinya tidak

\footnotetext{
${ }^{32}$ Sugeng, Pemilik UD. Wahyu Plastik, Wawancara di Kendari, 23 April 2016

${ }^{33}$ Marthon, Said Sa'ad, Ekonomi Islam di Tengah Krisis Ekonomi Global, (Jakarta: Zikrul Hakim, 2004), h. 43

${ }^{34}$ Fauzia, Ika Yunia dan Abdul Kadir Riyadi, ..., LocCit, h. 118-122
} 
produktif dan menjadi sia-sia sekarang menjadi tempat usaha yang produktif yang dapat diperoleh manfaatnya.

b. Faktor Tenaga Kerja

Setiap perusahaan suadah pasti membutuhkan tenaga kerja sebagai karyawan yang dengan aktivitasnya dapat menjalankan roda perusahaan, sehingga tanpa didukung dengan adanya tenaga kerja/karyawan maka perusahaan tidak bisa berjalan dengan baik. Dalam penyediaan tenaga kerja, pihak UD. Wahyu Plastik tidak menspesialisasikan keahlian dalam rekrutmen karyawan. Tenaga kerja yang ada tinggal disekitar lokasi produksi mereka langsung datang ke UD. Wahyu Plastik untuk bekerja.

Pemberian upah yang dilakukan UD. Wahyu Plastik menggunakan sistem upah prestasi atau satuan produk sehingga perusahaan akan memberikan imbalan kepada tenaga kerja untuk setiap jumlah produk yang dihasilkan berdasarkan unit produk yang diselesaikannya. Upah yang diberikan untuk setiap kilogram yang diselesaikan sebesar Rp. 1.500,-. Untuk mengejar target ditetapkan pekerjaan tertentu dan harus diselesaikan dalam jangka waktu tertentu. ${ }^{35}$

Upah pekerja akan dibayarkan jika produk sudah terjual, hal ini tidak sesuai dengan Hadits yang diriwayatkan Ibnu Majjah dari Ibnu Umar r.a yang menceritakan bahwa Rasulullah SAW bersabda "bayarlah upah/gaji itu sebelum kering keringat pekerjanya". Namun demikian, sistem pembayaran upah tenaga kerja di UD. Wahyu Plastik tidak bertentangan dengan sistem ekonomi Islam dikarenakan sistem pemberian upah tenaga kerja tersebut berdasarkan kesepakatan awal ketika mereka mau bekerja sebagaimana petunjuk Hadits Raulullah SAW yang diriwayatkan oleh Abdurrazak dari Abi Said al Khudri ra. Sesungguhnya Nabi saw. bersabda "barang siapa mempekerjakan seorang pekerja, maka harus disebutkan upahnya".

Bonus/hadiah THR juga diberikan kepada karyawan UD. Wahyu Plastik selain upah sebagai bentuk penghargaan terhadap produktifitas pekerjaan yang dapat memberikan keuntungan kepada perusahaan. ${ }^{36}$

\section{c. Faktor Modal}

Modal merupakan bagian yang diperlukan untuk memulai ataupun ketika menjalankan sebuah bisnis meskipun bagi sebagian orang modal bukan menjadi alasan satu-satunya untuk memeiliki sebuah usaha, namun bagi UD. Wahyu Plastik merasakan modal sangat utama yang diperlukan diperlukan terutama ketika omset perusahaan menurun bahkan mendekati kebangkrutan akibat persaingan yang cukup ketat, sehingga untuk bangkit

\footnotetext{
${ }^{35}$ Marthon, Said Sa'ad, ...Op. Cit.

${ }^{36}$ ibid
} 
kembali perusahaan memerlukan dana yang tidak sedikit karna dalam usaha pengolahan limbah untuk mendapatkan bahan baku dari plastik bekas harus membeli secara tunai dari para pemulung sementara hasil olahan belum tentu dapat terjual pada saat itu juga. ${ }^{37}$

Sumber modal pengolahan limbah plastik UD. Wahyu plastik terbagi kepada dua, yaitu:

1) Modal pribadi; Modal pribadi merupakan modal yang didapat dari harta pemilik usaha yang digunakan pada awal pendirian usaha untuk membeli tanah lahan produksi, membeli mesin penggilingan plastik serta membeli plastik bekas dari para pemulung.

2) Modal dari pinjaman Bank; Modal dari hasil pinjaman Bank digunakan untuk pengembangan usaha yang sebelumnya mengalami kerugian dengan menjaminkan tanah tempat usaha.

\section{d. Faktor Manajemen}

UD. Wahyu Plastik merupakan badan usaha perorangan. Manajemen perusahaan menggunakan manajemen sederhana dimana semua pengaturan dilakukan oleh pemilik usaha yang bertanggung jawab terhadap kegiatan perusahaan baik merencanakan, memantau, memasarkan hasil produksi serta mengambil kebijakan tindakan perbaikan bila diperlukan.

Fungsi manajerial UD. Wahyu plastik berdasarkan fungsi manjemen adalah sebagai berikut:

1) Fungsi Perencanaan (planing); Untuk keberlangsungan dan kemajuan usahanya, pihak manajemen menyeimbangkan antara pasokan bahan baku dan kebutuhan tingkat produksi dengan mencari sumber-sumber pemasok bahan baku yakni para pemulung, langkah yang dilakukan adalah membeli dengan harga sesuai pasar.

2) Fungsi Pengorganisasian (organizing); Rekrutmen pegawai di UD. Wahyu Plastik disesuaikan kebutuhan dan ditempatkan pada beberapa bagian sehingga setiap tenaga kerja melakukan aktivitas produksi sesuai tugas yang sudah ditetapkan manajemen.

3) Fungsi Pengarahan (directing); Dalam melakukan aktivitas produksinya tidak semua tenaga kerja langsung dapat menghasilkan produk berkualitas, untuk itu diperlukan pengarahan agar setiap pekerja memahami tugas masing-masing.

4) Fungsi Pengawasan (controlling); Untuk mendapatkan produk yang berkualitas pihak manajemen melakukan pengontrolan baik pada bagian pemisahan, pembersihan, penggilingan ataupun pada saat

\footnotetext{
${ }^{37}$ Ibid
} 
pengepakan, hal itu dilakukan supaya tidak terdapat kesalahan prosedur produksi yang akan berakibat pada kualitas hasil gilingan.

e. Faktor Teknologi

Produksi pengolahan limbah plastik sangat dipengaruhi mesin yang baik sehingga dapat menambah jumlah produk serta menambah perolehan laba perusahaan. Jenis mesin yang digunakan untuk proses produksi limbah plastik adalah:

1) Mesin press yang digunakan untuk menggencet bahan baku sebelum digiling.

2) Mesin penggilingan/rajahan adalah mesin yang digunakan untuk menggiling bahan baku menjadi potongan-potongan kecil.

3) Mesin pembuat biji plastik yaitu mesin yang digunakan untuk mencairkan hasil potongan plastik kemudian disaring/cetak dan akan menghasilkan butiran-butiran plastik.

4) Mesin pencetak produk daur ulang seperti mesin pencetak botol, mesin pencetak gelas, mesin pencetak mainan dari plastik dan lainlain.

Dari beberapa jenis mesin penunjang produk daur ulang plastik yang ada, UD. Wahyu Plastik baru menghasilkan gilingan/rajahan plastik dikarenakan UD. Wahyu Plastik baru memiliki satu jenis mesin yaitu mesin penggiling/perajah. Bahkan dalam proses penggencetan bahan baku sebelum digiling/rajah UD. Wahyu Plastik melakukannya dengan cara manual yakni diinjak karena tidak memiliki mesin press, hal itu menyebabkan proses penggencetan membutuhkan waktu yang lama.

f. Faktor Bahan Baku

Bahan baku yang digunakan dalam produksi pengolahan limbah plastik adalah plastik bekas yang diperoleh dari para pemulung. Untuk mengantisipasi pasokan bahan baku UD. Wahyu Plastik bekerjasama dengan para pemulung yang menjual plastik bekas dengan harga yang disepakati.

\section{G. PROSES PRODUKSI DI UD. WAHYU PLASTIK KENDARI}

Jumlah sampah yang semakin meningkat tidak diikuti dengan peningkatan kapasitas tempat pembuangan sampah dapat mengakibatkan pencemaran lingkungan terutama sampah dari jenis plastik yang tidak mudah hancur memerlukan penangan yang cukup serius. Berdasarkan data yang dimiliki Dinas Kebersihan Pertamanan dan Pemakaman Kota Kendari diketahui bahwa warga Kota Kendari memproduksi sampah 541,78 m3 yang meliputi sampah yang bisa terurai secara alamiah seperti sisa makanan serta sampah yang sulit terurai secara alamiah seperti plastik. Dari total angka 
tersebut, yang mampu diangkut ke Tempat Pembuangan Akhir oleh Dinas Kebersihan Pertamanan dan Pemakaman Kota Kendari berkisar 308 m3, sehingga $237 \mathrm{~m} 3$ sisanya tak terangkut. ${ }^{38}$

Kehadiran perusahaan daur ulang limbah plastik sangat membantu dalam penanganan limbah plastik. Untuk menjadi produk baru hasil olahan limbah plastik akan melibatkan kelompok berikut:

a. Pemulung dan Pengumpul plastik bekas; Pemulung yaitu orang yang mengumpulkan plastik bekas langsung dari tempat-tempat sampah/tempat pembuangan akhir sampah ataupun langsung dari masyarakat, nantinya akan dijual kepada pihak pengolah limbah plastik. Pengumpul plastik bekas merupakan orang/masyarakat yang menyimpan plastik bekas digunakan kemudian menjualnya sehingga mendapatkan nilai ekonomis dari limbah plastik.

b. Pengolah limbah plastik yaitu orang/kelompok yang memiliki usaha pengolahan sampah plastik baik pengepresan, penggilingan/rajahan, bijih plastik.

c. Pabrik plastik yaitu perusahaan yang mendaur ulang limbah plastik menjadi produk baru seperti ember, rak plastik, hanger/gantungan baju dan lain-lain. ${ }^{39}$

UD. Wahyu Plastik berada pada katagori kelompok kedua yakni pengolah limbah plastik yang hasil produksinya hanya sampai pada tahap penggilingan/perajahan yang nantinya akan dijual kepada perusahaan pengolah limbah plastik yang sudah memproduksi bijih plastik. ${ }^{40}$ Tahapan untuk menghasilkan gilingan/rajahan plastik UD. Wahyu Plastik sebagai berikut:

a. Mendatangkan bahan baku. Bahan baku yang akan digunakan merupakan plastik-plastik bekas dengan berbagai bentuk seperti gelas atau botol serta tutup botol berbahan plastik, pembungkus kabel, tas plastik, mainan, tutup monitor, wadah yang dicetak, pot tanaman, perkakas dari plastik, kotak CD, dan lain-lain. ${ }^{41}$

b. Mengelompokkan/mensortir plastic. Mengelompokkan/mensortir plastik merupakan kegiatan memisahkan plastik berdasarkan jenis dan warna sehingga hasil penggilingan/perajahan suadah satu jenis plastik

Maret 2016.

${ }^{38} \mathrm{http}: / /$ www.menlhal.go.id/pengelolaan-sampah-kota-kendari. Diakses tanggal 10

${ }^{39} \mathrm{ibid}$

${ }^{40}$ ibid

${ }^{41}$ Sri, Bagian memilih/memisahkan limbah plastik, wawancara di Kendari, 7 Mei 2016 
dengan warna yang sama, karna kwalitas hasil rajahan akan berpengaruh pada harga jual. ${ }^{42}$

c. Pembersihan dan pencucian. Limbah plastik sebagai bahan baku yang baru dibeli dari para pemulung meskipun sudah dipisahkan dan dikelompokkan berdasarkan jenis dan warna, tetapi masih memerlukan pembersihan dari kotoran ataupun tanah serta bahan-bahan yang digunakan sebagai merek/label baik berupa kertas, plastik yang tidak sejenis atau bahan apapun yang melekat dengan mencuci bahan baku yang akan digiling sehingga tidak mengurangi kualitas hasil gilingan. ${ }^{43}$

d. Penggilingin/perajahan. Penggilingin/perajahan dilakukan setelah bahan baku dibersihkan dengan cara memasukkan plastik ke dalam mesin yang sudah dinyalakan. Mesin penggilingan tersebut memiliki pisau untuk memotong plastik yang pada bagian atas mesin terdapat corong untuk memasukkan air dan deterjen sehingga memudahkan untuk melakukan penggilingan serta sebagai sarana pencucian plastik yang sedang digiling. Hasil penggilingan menjadikan plastik mengalami pencacahan dengan ukuran sesuai saringan yang terdapat di dalam mesin. ${ }^{44}$

e. Pengepakan hasil gilingan. Hasil gilingan plastik yang sudah dibersihkan dan dikeringkan kemudian dimasukkan ke dalam karung yang nantinya akan dijual kepada perusahaan pembuat bijih plastik atau perusahaan-perusahaan produksi yang bahan bakunya dari plastik seperti pabrik mainan plastik, pabrik alat-alat rumah tangga berbahan plasti, dan lain sebagainya.

Tahapan proses produksi limbah plastik di UD. Wahyu plastik adalah sebagai berikut:

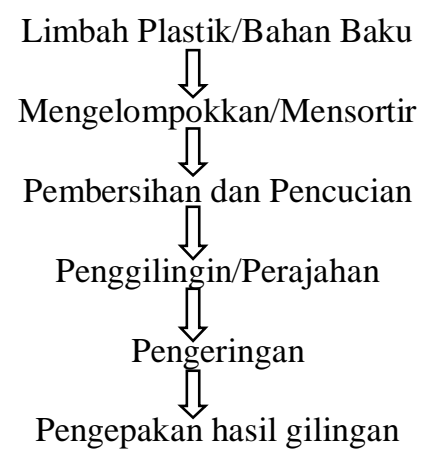

${ }^{42}$ Ibid

${ }^{43}$ Yati, Bagian Membersihkan Limbah Plastik, wawancara di Kendari, 7 Mei 2016

${ }^{44}$ Abdul Rohman, Bagian Menggiling Limbah Plastik, wawancara di Kendari, 7 Mei 2016 


\section{H. TINJAUAN EKONOMI ISLAM TERHADAP PENGOLAHAN LIMBAH PLASTIK DI UD. WAHYU PLASTIK KENDARI}

Ekonomi Islam dibangun atas dasar Al-Qur'an dan sunnah Rasulullah saw. sehingga memiliki prinsip konsep yang tetap, meskipun pada prakteknya pada situasi dan kondisi tertentu bisa saja berlaku luwes bahkan mengalami perubahan. ${ }^{45}$ Sistem ekonomi Islam yang berpegang teguh kepada Al-qur'an dan Sunnah Rasulullah saw. memiliki prinsip dan nilai dasar yang salah satunya adalah kesejahteraan individu dan masyarakat, oleh karenanya maka setiap kegiatan ekonomi tidak boleh bertentangan dengan semangat prinsip ekonomi tersebut.

Pemahaman gambaran ekonomi Islam pada produksi pengolahan limbah plastik di UD. Wahyu Plastik adalah sebagai berikut:

a. Tinjauan Terhadap Keberadaan UD. Wahyu Plastik

Islam mengajarkan keseimbangan kehidupan baik spiritualmaterialisme, individual-sosial, jasmani-rohani serta duniawi-ukhrowi. Islam tidak ingin umatnya hidup dalam kemiskinan, oleh karenanya kekayaan materi merupakan bagian penting dalam kehidupan manusia. Islam juga tidak menghendaki umatnya bergelimang dalam budaya materialism, sehingga kegiatan ekonomi dalam Islam tidak hanya bersifat materi melainkan juga memiliki nilai ibadah. Semua aktivitas ekonomi (produksi, distribusi dan konsumsi) yang dilakukan harus menjadi suatu usaha untuk mendapatkan keridhaan dan rahmat dari Allah SWT. sehingga tujuan falah yakni mendapakan kebahagiaan dan keuntungan dunia akhirat dalam berekonomi akan tercapai.

Secara umum, aktivitas produksi di UD. Wahyu Plastik dalam perspektif ekonomi Islam menitik beratkan pada:

1) Memenuhi kebutuhan hidup seseorang secara sederhana, dimana setiap pekerja bisa memenuhi kebutuhan primernya seperti makanan, minuman, pakaian, tempat tinggal.

2) Memenuhi kebutuhan keluarga; Kewajiban dan tanggung jawab sebagai suami ataupun hak yang dimiliki istri untuk memenuhi kebutuhan keluarga menimbulkan konsekwensi bagi suami ataupun istri untuk bekerja demi mendapatkan hasil sebagai sarana pemenuhan kebutuhan keluarga yang memungkinkan terciptanya suasana tentram dan bahagia dalam lingkunga rumah tangga.

${ }^{45}$ Izzan, Ahmad dan Syahril Tanjung, Referensi Ekonomi Syariah Ayat-ayat AlQur'an yang Berdimensi Ekonomi, (Bandung: PT Remaja Rosdakarya Offset, 2006), h. 32. 
b. Tinjauan terhadap Produksi UD. Wahyu Plastik

Produksi UD. Wahyu Plastik dalam mengolah limbah plastik secara umum mampu mewujudkan kemandirian umat dengan berkontribusi bagi penghasilan karyawannya sehingga mampu memberikan penghidupan untuk memenuhi kebutuhan diri dan keluarga.

Produk yang dihasilkan merupakan produk yang diperbolehkan oleh syariat atau tidak ada pelarangannya dalam syariat sehingga secara umum tidak bertentangan dengan sistem pada produksi dalam ekonomi Islam. Proses produksi yang dilakukan UD. Wahyu Plastik dimulai dari pengadaan bahan baku, pemilahan, pembersihan, penggilingan sampai pada pengepakan.

1) Proses Pengadaan Bahan Baku

Bahan baku sebagai bahan utama produksi didapatkan dari para pemulung yang menjual plastik dengan jenis yang dapat diproduksi di UD. Wahyu Plastik. Para pemulung biasanya mendapatkan plastik dari lingkungan, tempat pembuangan sampah (TPS), tempat pembuangan akhir (TPA) atau dari masyarakat yang menyimpan plastik bekas kemudian menjualnya. Plastik-plastik bekas tersebut dibersihkan secara sederhana dengan hanya menghilangkan tanah atau kotoran terlebih dahulu sebelum dibeli UD. Wahyu Plastik. ${ }^{46}$

2) Proses pemisahan/Pemilahan

Pemisahan/pemilahan merupakan bagian mensortir plastik bekas sebagai bahan baku berdasarkan jenis dan warna plastik. Pemisahan tersebut dilakukan untuk mendapatkan hasil olahan dengan jenis atau warna plastik yang sama sehingga dapat berakibat pada kualitas dan harga produksi hasil gilingan/rajahan.

3) Proses Pembersihan dan pencucian

Bahan baku yang sudah dipisahkan/dipilah kemudian dibersihkan dari kotoran yang masih ada dengan menggunakan air. Proses pembersihan dan pencucian tersebut bertujuan untuk menghilangkan kotoran yang tersisa sehingga dapat meningkatkan kualitas hasil gilingan menjadi bersih. Selain itu, proses pembersihan dan pencucian dalam sistem syariah berarti dapat menghilangkan najis pada benda tersebut.

4) Proses Penggilingan

Penggilingan bahan baku merupakan proses untuk memotong/merajah bahan baku menjadi kecil dengan cara

${ }^{46}$ Rohman, Pemasok Bahan Baku/Pemulung Plastik Bekas. Wawancara di Kendari, 21 Mei 2016 
memasukkan plastik ke dalam mesin yang sudah dinyalakan. Mesin penggilingan tersebut memiliki pisau untuk memotong plastik, dibagian atas mesin terdapat corong yang berguna untuk memasukkan air yang dapat dicampur dengan deterjen sehingga dapat memudahkan melakukan proses penggilingan yang sekaligus sebagai sarana mencuci plastik yang sedang digiling. Hasil penggilingan menjadikan plastik mengalami pencacahan dengan ukuran kecil.

5) Proses pengeringan setelah penggilingan

Pengeringan setelah penggilinga dilakukan supaya hasil gilingan yang ditimbang memiliki berat sesuai dengan banyaknya, bukan mengalami peningkatan berat akibat banyaknya air. Dalam sistem ekonomi Islam, kejujuran pada berat timbangan berarti tidak ada manipulasi apapun sehingga berat bahan tidak sesuai dengan berat dari volume bahan tersebut.

6) Proses Pengepakan

Pengepakan merupakan proses memasukkan hasil gilingan/rajahan yang sudah dikeringkan ke dalam karung. Pengepakan bertujuan untuk memudahkan penimbangan produk hasil gilingan yang nantinya akan dipasarkan/dijual.

Dari uraian penjelasan proses produksi di UD wahyu tidak bertentangan dengan maqashid al-syari'ah mengenai prinsip produksi dalam ekonomi Islam, yaitu:

1) Produksi yang dilakukan UD. Wahyu Plastik merupakan pengolahan limbah plastik yang tidak diharamkan oleh syari'ah sehingga tidak bertentangan dengan penjagaan terhadap agama, jiwa, akal, keturunan maupun harta.

2) Hasil produksi pengolahan limbah plastik yang dilakukan UD. Wahyu Plastik menjadi bahan baku yang bisa dicetak menjadi biji plastik sebagai rangkaian pengolahan bahan bahan jadi yang terbuat dari plastik seperti ember, botol plastik, gelas plastik, permainan yang terbuat dari plastik dan lain-lain yang kesemuanya bisa menjadi penunjang/mendukung bagi kemudahan dan kenyamanan hidup manusia.

3) Pengolahan limbah plastik merupakan produksi dengan bahan baku sampah berbahan plastik yang tidak mudah terurai, jika dibiarkan di alam/lingkungan/tanah dapat merusak lingkungan. Sehingga produksi pengolahan limbah plastik dapat membantu mengurangi kerusakan lingkungan yang diakibatkan pencemaran sampah plasti. 
4) Keadilan pendapatan yang diperlihatkan UD. Wahyu Plastik adalah dengan pembayaran sesuai kesepakatan antara pemilik usaha dengan para tenaga kerja yang disesuaikan dengan pendapatan hasil penjualan dikurangi biaya oprasional.

\section{PELUANG USAHA PENGOLAHAN LIMBAH PLASTIK}

Peluang usaha merupakan kesempatan yang ada pada suatu peristiwa yang dapat dimanfaatkan untuk mendapatkan apa yang diinginkan dalam usaha yang dilakukan dengan memanfaatkan berbagai sumberdaya yang dimiliki. Kemampuan membaca peluang merupakan dasar berwirausaha selain kreatifitas yang dapat dituangkan melalui kecukupan waktu untuk berwirausaha serta memiliki dorongan yang kuat dalam menguasai pasar. ${ }^{47}$

Bisnis pengolahan limbah plastik merupakan bisnis yang selain menghasilkan nilai ekonomi juga dapat bermanfaat untuk mengurai limbah plastik menjadi produk siap pakai. Beberapa peluang usaha yang berhubungan dari pengolahan limbah plastik, diantaranya adalah:

a. Terciptanya lapangan pekerjaan

Produksi limbah plastik merupakan usaha yang memiliki mata rantai antara usaha satu dengan lainnya. Mata rantai usaha tersebut adalah:

1) Pemulung dan pengumpul plastik bekas; merupakan orang yang mengumpulkan plastik bekas langsung dari tempat-tempat sampah/tempat pembuangan akhir sampah atau orang/masyarakat yang menyimpan plastik bekas digunakan kemudian menjualnya sehingga mendapatkan nilai ekonomis dari limbah plastik.

2) Pengolah limbah plastik; merupakan orang/kelompok yang memiliki usaha pengolahan limbah plastik. Peluang bisnis pengolahan limbah plastik dibedakan menjadi:

a) Bisnis pengepresan limbah plastik; bisnis pengepresan menjalankan usahanya hanya mengepres/menipiskan bahan baku dengan menggunakan alat press yang nantinya dipasarkan/dijual pada perusahaan yang akan menggiling/merajah plastik bekas.

b) Bisnis penggiling/perajahan limbah plastik; bisnis penggilingan/perajahan limbah plastik menjalankan usahanya dengan menggunakan mesin penggiling/perajah yang dapat menghasilkan potongan-potongan plastik dalam bentuk rajahan.

${ }^{47}$ Alfianto, Eko Agus, "Kewirausahaan: sebuah Kajian Pengabdian Kepada Masyarakat", Jurnal Heritage, Vol. 1, No. 2, (2012): 34. http://jurnal.yudharta.ac.id/wpcontent/uploads/2014/07/Kewirausahaan.pdf 
c) Bisnis pembuatan bijih plastik; bisnis pembuatan bijih plastik menjalankan usahanya dengan menggunakan mesin yang mampu mencairkan plastik kemudian dicetak yang menghasilkan butiran-butiran bijih plastik.

d) Bisnis daur ulang limbah plastik yaitu sebuah usaha yang mendaur limbah plastik menjadi produk yang memiliki manfaat guna dengan memanfaatkan limbah plastik sebagai bahan baku pembuatan kerajinan seperti pot bunga, keranjang, dan lain sebagainya.

e) Perusahaan produksi yang bahan bakunya dari plastik yakni perusahaan yang menghasilkan produk siap pakai seperti gelas plastik, piring plastik, rak sepatu, mainan berbahan plastik, ember dan lain sebagainya.

b. Akses pemasaran hasil olahan yang berbahan baku limbah plastik.

Pemasaran merupakan tujuan dari produksi, karena sehebat apapun sebuah produk jika tidak laku dipasaran berakibat kerugian bagi perusahaan. Hasil produk berbahan plastik merupakan slah satu produk yang banyak diminati masyarakat karena karena keunggulan yang dimiliki produk berbahan plastik diantaranya ringan, tahan air, harganya terjangkau. Oleh karenanya, semakin banyak orang menggunakan produk berbahan plastik akan semakin banyak kebutuhan bahan baku setiap bentuk bisnis olahan limbah plastik.

Mata rantai produksi limbah plastik dapat dijelaskan sebagai berikut:

a. Konsumen; merupakan individu ataupun masyarakat yang menggunakan produk berbahan plastik dan pada akhirnya plastik tersebut akan dibuang menjadi sampah plastik karena kerusakan atau masa pakainya sudah tidak dapat digunakan kembali.

b. Sampah/limbah plastik; merupakan hasil buangan individu, rumah tangga maupun perusahaan yang berbahan plastik dan dimanfaatkan oleh pemulung/pengepul.

c. Pemulung/pengepul; merupakan orang ataupun kelompok yang memanfaatkan sampah/limbah plastik sehingga memiliki nilai ekonomis dengan menjualnya kepada pengolah limbah plastik.

d. Pengolah limbah plastik yaitu orang/kelompok yang memiliki usaha pengolahan sampah plastik baik pengepresan, penggilingan/rajahan, bijih plastik.

d. Perusahaan pembuat produk jadi yaitu perusahaan yang mendaur ulang limbah plastik menjadi produk baru seperti ember, rak plastik, hanger/gantungan baju dan lain-lain. 
Mata rantai produksi pengolahan limbah plastik digambarkan sebagai berikut:

\section{J. PENUTUP}

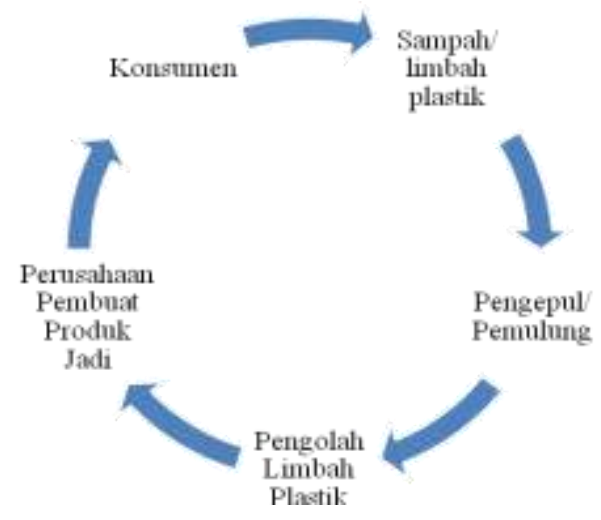

Faktor-faktor produksi yakni tanah, tenaga kerja, modal, teknologi serta manajemen memiliki peran penting dalam oprasional pengolahan limbah plastik di UD. Wahyu Plastik Kendari. Untuk menghasilkan produk siap jual harus melalui beberapa tahapan/proses sehingga menghasilkan produk olahan limbah plastik berkualitas. Proses yang dilakuakn di UD. Wahyu Plastik adalah mendatangkan bahan baku, mengelompokkan/mensortir plastik, pembersihan dan pencucian, penggilingin/perajahan, pengeringan hasil rajahan serta pengepakan.

Keberadaan UD. Wahyu Plastik Kendari yang bergerak dalam bisnis pengolahan limbah plastik selain membantu mengurangi sampah plastik yang dapat mencemari lingkungan, juga memberikan nilai tambah ekonomi bagi tenaga kerjanya.

Produk yang dihasilkan UD. Wahyu Plastik merupakan produk yang diperbolehkan oleh syariat, sehingga secara umum tidak bertentangan dengan sistem produksi dalam Islam, hal itu terlihat pada proses produksi mulai dari pengadaan bahan baku, pemilahan, pembersihan, penggilingan sampai pada pengepakan.

Pengolahan limbah plastik merupakan bisnis yang memiliki mata rantai tidak terpisahkan dengan usaha sejenis yakni pemulung/pengumpul plastik bekas, Pengolah limbah plastik serta pabrik yang memproduksi bahan-bahan dari plastik. Dengan mata rantai tersebut, peluang usaha pengolahan limbah plastik sangat besar.

\section{DAFTAR PUSTAKA}


A. Djazuli, Yadi Janwari. Lembaga-Lembaga Perekonomian Umat (Sebuah Pengenalan.; Jakarta: PT. Raja Grafindo Persada 2002.

Alfianto, Eko Agus. "Kewirausahaan: sebuah Kajian Pengabdian Kepada Masyarakat". Jurnal Heritage. Vol. 1 No. 2, (2012).

Aslam, Mohamed Heneef. Pemikiran Ekonomi Islam Kontemporer. Terj. Suherman Rosyidi; Jakarta: Rajawali, 2010.

Daniel, Valerina. Easy Green Living. Bandung: Hikmah, 2009.

Efendi, Mochtar. Ekonomi Islam Suatu Pendekatan Berdasarkan Ajaran AlQur'an dan Hadits. Palembang: YPII Al-Muktar, 1996.

Fuad, Zaki Chalil. Pemerataan Distribusi Kekeyaan dalam Ekonomi Islam. Jakarta: Erlangga, 2009.

Gitosudarmo, H. Indriyo, Manajemen Operasi, Edisi Kedua. Yogyakarta: BPFE Yogyakarta, 2002.

Hadiyan, Edwin. "Sistem Pengupahan Tenaga Kerja Ditinjau Dari Prinsip Fiqih Muamalah Dan Undang-undang No. 13 tahun 2003 Tentang Ketenagakerjaan". Jurnal Bisnis dan Manajemen, Vol. 3, No. 1, (2015): 24-33.

Izzan, Ahmad dan Syahril Tanjung. Referensi Ekonomi Syariah Ayat-ayat Al-Qur'an yang Berdimensi Ekonomi. Bandung: PT Remaja Rosdakarya Offset, 2006.

K. Lubis, Suhrawardi. Hukum Ekonomi Islam. Cet. 1. Jakarta: Sinar Grafika, 2000.

Koto, H. Alaiddin. Ilmu Fiqih dan Ushul Fiqih. Jakarta: Grafindo Pratama, 2004.

Mansyur, Kahar. Bulughul Maram. Jakarata: PT. Rineka Cipta, 1992.

Marthon, Said Sa'ad. Ekonomi Islam di Tengah Krisis Ekonomi Global. Jakarta: Zikrul Hakim, 2004.

Nata, Abuddin. Studi Islam Komprehenshf. Jakarta: Kencana Prenada Media Group, 2011.

R. Uno, Mien dan Siti Gretiani, Buku Pintar Etiket Hijau. Jakarta: Gramedia, 2011.

Rahman, Afzalur. Economic Doktrines of Islam, Terj. Soeroyo dan Nastangin, "Doktrin Ekonomi Islam", Jilid II. Yogyakarta: PT Dana Bhakti Wakaf, 1995.

S.P. Hasibuan, Malayu. Dasar-Dasar Perbankan. Jakarta: Bumi Aksara, 2004.

Shihab, M. Quraish. Menabur Pesan Illahi Al-Qur'an dan Dinamika Kehidupan Masyarakat.; Jakarta: Lentera Hati, 2006. 
Simanjuntak, Payaman. Manajemen Hubungan Industrial. Jakarta: Pustaka Sinar Harapan, 2003.

W. Griffin, Ricki, et al. Bisnis, Alih Bahasa Edina C. Tarmidzi, Edisi 6. Jakarta: Prenhallindom, 2003.

Zulkifli, Arif. Dasar-Dasar Ilmu Lingkungan. Jakarta: Salemba Teknika, 2014.

\section{Website:}

Bongardt, Benjamin. Masalah Sampah Plastik. http://www.dw.com/id/masalah-sampah-plastik/g-17164855

Pratiwi, Irma Hardi, Sritomo Wignjosoebroto, dan Dyah Santhi Dewi. Sistem Pengelolaan Sampah Plastik Terintegrasi Dengan Pendekatan Ergonomi Total Guna Meningkatkan Peran Serta Masyarakat (Studi Kasus: Surabaya), http://dosen.narotama.ac.id/. Diakses tanggal 10 Maret 2016

Purwaningsih, Dyah. Pemanfaatan Daur Ulang Limbah Plastik Dan Logam Untuk Sumber Pembuatan Peraga Pendidikan Inovatif, http://staff.uny.ac.id/. Diakses tanggal 8 Desember 2015.

Hindari Budaya Nyampah". http://www.p-wec.org/id/go-green/hindaribudaya-nyampah.

Pengelolaan Sampah Kota Kendari. http://www.menlhal.go.id/pengelolaansampah-kota-kendari. 